\title{
MERANCANG ALAT PENDETEKSI BORAKS PADA BAKSO MENGGUNAKAN METODE LOGIKA FUZZY BERDASARKAN SENSOR WARNA DAN LED (LIGHT EMITTING DIODE) BERBASIS ANDROID
}

\author{
N. Turilah ${ }^{1}$, I. W. Sudarsana ${ }^{2}$, dan D. Lusiyanti ${ }^{3}$ \\ 1,2,3Program Studi Matematika Jurusan Matematika FMIPA Universitas Tadulako \\ Jalan Soekarno-Hatta Km. 09 Tondo, Palu 94118, Indonesia. \\ 1hturilah50@gmail.com, ${ }^{2}$ sudarsanaiwayan@yahoo.co.id, ${ }^{3}$ desy.lusiyanti@untad.ac.id
}

\begin{abstract}
Meatballs are foods made from meat, shrimp, fish chopped and crushed together with starch and egg white, usually formed roundly. Meatballs have health benefits for the human body because of the content contained in animal protein, vitamins and fat. However, in the manufacture of meatballs for the benefit of many, sellers often use the wrong way by using borax chemicals on meatballs. Therefore, this study aims to build a design tool in the form of borax detection on meatballs based on android. The tool works by processing the input data obtained from a color sensor coupled with an LED (Light Emitting Diode) to the microcontroller on Arduino Uno R3. The data is processed by implementing the Mamdani fuzzy logic method as a decision to state the output output of borax detector on meatballs. Furthermore, the output output displayed on the device using a sample of 12 meatballs obtained tool accuracy of $75 \%$.
\end{abstract}

Keywords : Boraks, Color Sensor, Fuzzy Logic, Microcontroller, Meatball.

\section{ABSTRAK}

Bakso adalah makanan yang terbuat dari daging, udang, ikan yang dicincang dan dilumatkan bersama tepung kanji dan putih telur, biasanya dibentuk bulat-bulat. Bakso memiliki manfaat bagi kesehatan tubuh manusia karena kandungan yang terdapat berupa protein hewani, vitamin, dan lemak. Akan tetapi dalam pembuatan bakso demi keuntungan yang banyak, tak jarang penjual menggunakan cara yang salah dengan menggunakan bahan kimia boraks pada bakso. Oleh karena itu, penelitian ini bertujuan untuk membangun sebuah rancangan alat berupa pendeteksi boraks pada bakso yang berbasis android. Alat tersebut bekerja dengan mengolah data input yang diperoleh dari sensor warna yang dirangkaikan dengan lampu LED (Light Emitting Diode) ke mikrokontroler pada arduino uno R3. Data diolah dengan mengimplementasikan metode logika fuzzy Mamdani sebagai pengambilan keputusan untuk menyatakan keluaran output alat pendeteksi boraks pada bakso. Selanjutnya keluaran output ditampilkan pada perangkat dengan menggunakan sample sebanyak 12 bakso diperoleh akurasi alat sebesar $75 \%$.

Kata Kunci : Boraks, Sensor Warna, Logika Fuzzy, Mikrokontroler, Bakso Ikan. 


\section{PENDAHULUAN}

\subsection{Latar Belakang}

Menurut kamus besar bahasa Indonesia bakso adalah makanan terbuat dari daging, udang, ikan yang dicincang dan dilumatkan bersama tepung kanji dan putih telur, biasanya dibentuk bulat- bulat. Bakso memiliki manfaat bagi kesehatan tubuh manusia karena kandungan yang terdapat berupa protein hewani, vitamin, dan lemak.

Perdagangan bakso di Indonesia sudah mulai menyebar ke berbagai wilayah khususnya wilayah Sulawesi Tengah di Kota Palu. Pedagang bakso sudah banyak dijumpai dengan makanan yang terkadang membuat para konsumen tertipu dengan penampilan dan kelezatan pada makanan tersebut. Karena untuk mendapatkan keuntungan yang banyak, tak jarang penjual menggunakan cara yang salah dalam pembuatan bakso dengan menggunakan bahan kimia boraks. Menurut kamus besar bahasa Indonesia boraks adalah bahan pembersih (antiseptik); zat pembantu melelehkan zat padat) yang berupa hablur (kristal) berwarna kuning atau serbuk berwarna coklat. Menurut BPOM (Badan Pengawas Obatan Dan Makanan) hal ini berbahaya bagi kesehatan masyarakat yang mengonsumsi dalam kurun waktu yang lama dikarenakan boraks dapat meningkatkan resiko kanker hati. Boraks bersifat karsinogenik karena tidak mudah larut dalam air sehingga dapat menyebabkan gangguan tersebut.

Terkait permasalahan tersebut, mahasiswa FMIPA Universitas Negeri Yogyakarta yaitu Anggraeni, dkk. melakukan penelitian dengan membuat kertas whatman untuk analisis kadar boraks dalam makanan. Dalam hal ini, peneliti berpikir untuk mengembangkan penelitian kertas whatman menjadi alat pendeteksi boraks yang akan dikembangkan dengan sistem yang memonitoring analisis kandungan boraks menggunakan sensor warna dan lampu LED (Light Emitting Diode). Prinsip kerja dari sensor warna adalah membaca frekuensi warna pada bakso dan prinsip lampu LED (Lampu Emitting Diode) adalah sebagai indikator pembantu analisis kandungan boraks. Dengan menggunakan kedua prinsip kerja dari alat tersebut akan digabungkan kemudian diolah dengan menggunakan logika fuzzy yang hasilnya akan ditampilkan pada aplikasi yang dirancang berbasis android. Alat ini nantinya akan bisa mendeteksi boraks pada bakso dengan cepat tanpa harus melewati uji kimia yang agak sulit dan memakan banyak waktu serta lebih menampilkan hasil yang akurat.

\subsection{Rumusan Masalah}

Berdasarkan uraian latar belakang tersebut Rumusan masalah yang diambil dari penelitian ini adalah :

1. Bagaimana merancang alat pendeteksi boraks menggunakan sensor warna TCS 3200 dengan lampu LED (Lampu Emitting Diode)? 
2. Bagaimana cara mengetahui bakso yang mengandung boraks dan tidak mengandung boraks menggunakan metode logika fuzzy?

3. Bagaimana merancang aplikasi android untuk mendeteksi bakso yang mengandung boraks dan tidak mengandung boraks?

\title{
1.3. Batasan Masalah
}

Adapun beberapa hal yang dibatasi dalam penelitian ini yaitu:

1. Analisis bakso diukur dengan frekuensi warna.

2. Bakso yang digunakan dalam penelitian adalah bakso ikan.

3. Metode yang digunakan adalah metode logika fuzzy mamdani.

4. Software yang digunakan Arduino Genuino untuk memprogram mikrokontroler dan software App inventor untuk pembuatan aplikasi berbasis android.

\author{
II. METODE PENELITIAN \\ 1. Mempersiapkan Penelitian \\ 2. Studi Literatur \\ 3. Desain Akuisisi Data pada Mikrokontroler \\ 4. Desain Sistem Logika Fuzzy untuk Sistem Pengendali atau Pengontrol \\ 5. Simulasi \\ 6. Menyimpulkan Hasil Penelitian
}

\section{HASIL DAN PEMBAHASAN}

\subsection{Hasil}

\subsubsection{Pengumpulan Data}

Penelitian ini menggunakan data primer yaitu data kuantitatif berupa nilai-nilai hasil dari 2 variabel yang berdasarkan sensor warna dengan proses pembacaan warna terbagi menjadi warna dasar RG (Red and Green). Data yang digunakan adalah hasil pengukuran sensor warna. Pengukuran dilakukan pada bakso ikan yang mengandung boraks dan tidak mengandung boraks.

\subsubsection{Semesta Pembicaraan}

Penentuan semesta pembicaraan penelitian ini ditentukan dari hasil nilai yang dikeluarkan oleh sensor warna. Kemudian semesta pembicaraan diberi rentang dari nilai yang terkecil sampai yang terbesar. Adapun semesta pembicaraan ditunjukkan pada Tabel 1. 
Tabel 1 : Semesta Pembicaraan

\begin{tabular}{|c|c|c|}
\hline \multirow{2}{*}{ Fungsi } & Nama Variabel & Semesta Pembicaraan \\
\hline \multirow{2}{*}{ Input } & Red & {$[122-184]$} \\
\cline { 2 - 3 } & Green & {$[74-152]$} \\
\hline Output & Hasil & {$[0-10]$} \\
\hline
\end{tabular}

\subsubsection{Desain Aplikasi}

Sistem ini dibuat menggunakan App Inventor. Pada tampilannya memberikan 2 akses tombol, yaitu ANALISA dan Keluar. Tombol ANALISA berfungsi untuk menganalisa data yang telah diinput sehingga output dapat keluar pada monitor dan Tombol Keluar berfungsi untuk keluar dari sistem ini. Adapun tampilan sistemnya ditunjukkan pada Gambar 1.
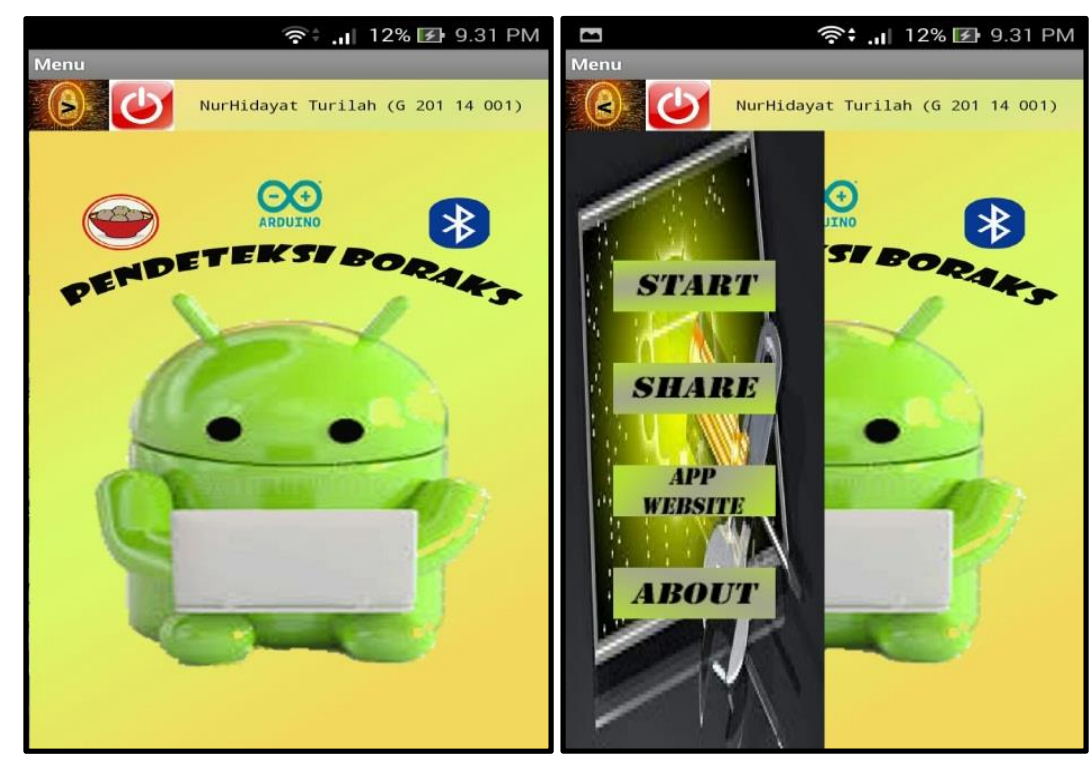

Gambar 1 : Tampilan screen

\subsubsection{Hasil Analisis dan Uji Coba}

Pengukuran dilakukan pada 12 sampel bakso untuk pengujian alat. Pengujian ini dilakukan untuk membandingkan output yang dihasilkan oleh alat terhadap sampel bakso yang tidak mengandung boraks. Hasil yang diperoleh dalam pengujian alat ini adalah bakso yang tidak mengandung boraks dengan pemberian nilai 1 dan nilai 0 untuk hasil yang lainnya. 
Berdasarkan hasil pengujian yang telah dilakukan maka diperoleh tingkat keakuratan alat sebagai berikut :

$$
\begin{aligned}
\text { Keakurasian data } & =\frac{\text { Jumlah data yang benar }}{\text { jumlah data }} \times 100 \% \\
& =\frac{9}{12} \times 100 \% \\
& =75 \%
\end{aligned}
$$

\subsection{Pengolahan Data secara manual}

\subsubsection{Himpunan Fuzzy}

Pada tahap ini, dibentuk himpunan fuzzy dan domain dari semesta pembicaraan. Penentuan domain dan himpunan fuzzy didasarkan pada pengamatan dan proses penelitian yang di alami dengan sensor warna.

Adapun model 3 variabel fuzzy yang dibangun dalam penelitian ini, yaitu :

1. Red : Terdiri dari 3 himpunan fuzzy yaitu Tidak Ada, Sedikit dan Banyak.

2. Green : Terdiri dari 2 himpunan fuzzy yaitu Tidak Ada, Sedikit dan Banyak

3. Hasil : Terdiri dari 3 himpunan fuzzy yaitu Non Boraks, Boraks KDR $1 \mathrm{gr}$ dan

Boraks LDR 1gr

\subsubsection{Variabel Red}

Untuk merepresentasikan variabel red digunakan Kurva representasi linear turun (untuk himpunan fuzzy sangat tidak ada), kurva segitiga (untuk himpunan fuzzy sedikit), dan kurva representasi linear naik (untuk himpunan fuzzy banyak). Adapun grafik Variabel Input Warna ditunjukkan pada Gambar 2.

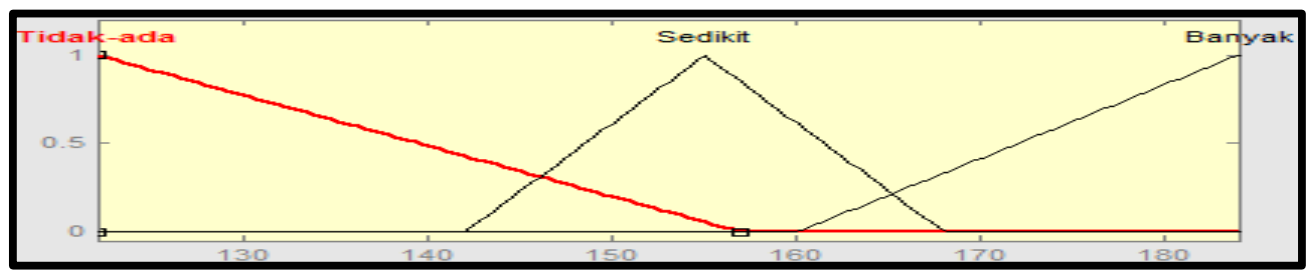

Gambar 2 : Grafik Variabel Input Red

\subsubsection{Variabel Green}

Untuk merepresentasikan variabel Green digunakan Kurva representasi linear turun (untuk himpunan fuzzy sangat tidak ada), kurva segitiga (untuk himpunan fuzzy sedikit), dan kurva representasi linear naik (untuk himpunan fuzzy banyak). Adapun grafik Variabel Input Warna ditunjukkan pada Gambar 3. 


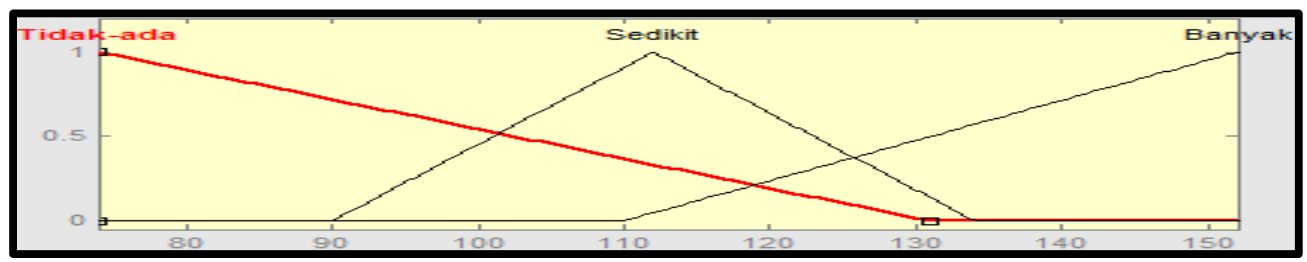

Gambar 3 : Grafik Variabel Input Green

\subsubsection{Variabel Hasil}

Untuk merepresentasikan variabel Green digunakan Kurva representasi linear turun (untuk himpunan fuzzy sangat Non Boraks), kurva segitiga (untuk himpunan fuzzy Boraks KDR $1 \mathrm{gr}$ ), dan kurva representasi linear naik (untuk himpunan fuzzy Boraks LDR 1gr). Adapun grafik Variabel Input Warna ditunjukkan pada Gambar 4.

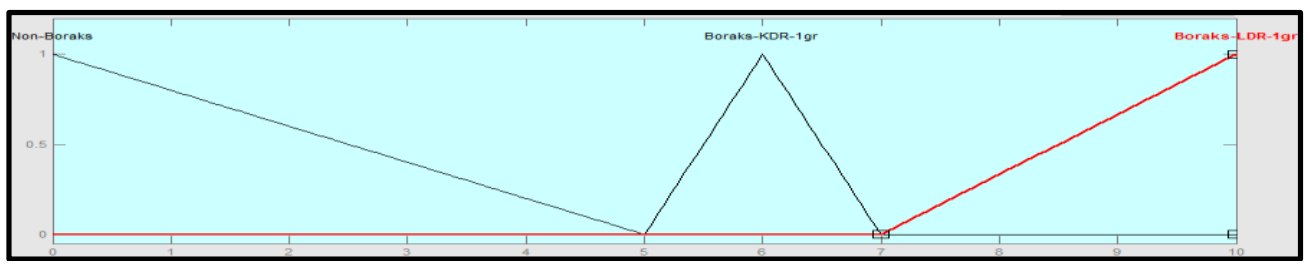

Gambar 4 : Grafik Variabel Output Hasil

\subsubsection{Rule Logika Fuzzy}

Setelah penentuan fungsi keanggotaan variabel maka dilakukan pembentukan aturanaturan logika fuzzy (rule). Aturan yang mungkin dan sesuai dengan basis pengetahuan dari 2 variabel input dan 1 variabel output berjumlah 9 rule, diantaranya sebagai berikut :

1. IF Red is Tidak Ada AND Green is Tidak Ada AND Hasil is Tidak Ada

2. IF Red is Sedikit AND Green is Tidak Ada AND Hasil is Sedikit

3. IF Red is Banyak AND Green is Sedikit AND Hasil is Banyak

4. IF Red is Tidak Ada AND Green is Sedikit AND Hasil is Tidak Ada

5. IF Red is Tidak Ada AND Green is Banyak AND Hasil is Tidak Ada

6. IF Red is Sedikit AND Green is Sedikit AND Hasil is Sedikit

7. IF Red is Sedikit AND Green is Banyak AND Hasil is Sedikit

8. IF Red is Banyak Ada AND Green is Banyak AND Hasil is Banyak

9. IF Red is Banyak AND Green is Tidak Ada AND Hasil is Banyak 


\subsubsection{Aplikasi Fungsi Implikasi}

Misalkan data yang dihitung adalah data pertama yaitu nilai $\operatorname{Red}=146$, dan Green $=$ 110, maka nilai keanggotaan dari setiap variabel input sebagai berikut :

- $\quad$ Red

a) Himpunan Fuzzy Tidak Ada

$$
\mu_{R \text { Tidak Ada }}\left(\frac{157-146}{35}\right)=0,31428571
$$

b) Himpunan Fuzzy Sedikit

$$
\mu_{R \text { Sedikit }}\left(\frac{146-142}{13}\right)=0,30769231
$$

- Green

a) Himpunan Fuzzy Tidak Ada

$$
\mu_{\text {R Tidak Ada }}\left(\frac{131-110}{57}\right)=0,36842105
$$

b) Himpunan Fuzzy Sedikit

$$
\mu_{R \text { Sedikit }}\left(\frac{110-90}{22}\right)=0,90909091
$$

Langkah selanjutnya, menentukan nilai keanggotaan dari rule-rule yang berlaku menggunakan metode Minimum ( $\alpha-c u t$ ). Rule yang terpengaruh nilai keanggotaannya adalah aturan 3 , aturan 4 dan aturan 5 . Adapun nilai-nilainya sebagai berikut :

1. Aturan 1 : IF Red is Tidak Ada AND Green is Tidak Ada THEN Hasil is Tidak Ada

$$
\begin{aligned}
\alpha_{1} & =\mu_{R \text { Tidak ada }}(146) \wedge \mu_{G \text { Tidak ada }}(110) \\
& =\min \left(\mu_{R_{\text {Tidak ada }}}(146), \mu_{G \text { Tidak ada }}(110)\right) \\
& =\min (0.31428571,0.36842105) \\
& =0.31428571
\end{aligned}
$$

2. Aturan 2 : IF Red is Sedikit AND Green is Tidak Ada THEN Hasil is Sedikit

$$
\begin{aligned}
\alpha_{2} & =\mu_{R \text { Sedikit }}(146) \wedge \mu_{G \text { Tidak ada }}(110) \\
& =\min \left(\mu_{R} \text { Sedikit }(146), \mu_{G \text { Tidak ada }}(110)\right) \\
& =\min (0.30769231,0.36842105) \\
& =0,30769231
\end{aligned}
$$

3. Aturan 4 : IF Red is Tidak Ada AND Green is Sedikit THEN Hasil is Tidak Ada

$$
\begin{aligned}
\alpha_{4} & =\mu_{R_{\text {Tidak ada }}}(146) \wedge \mu_{G \text { Sedikit }}(110) \\
& =\min \left(\mu_{R_{\text {Tidak ada }}}(146), \mu_{G \text { Sedikit }}(110)\right) \\
& =\min (0.31428571,0.90909091) \\
& =0.31428571
\end{aligned}
$$

4. Aturan 6 : IF Red is Sedikit AND Green is Sedikit THEN Hasil is Sedikit

$$
\begin{aligned}
\alpha_{6} & =\mu_{R \text { Sedikit }}(146) \wedge \mu_{G \text { Sedikit }}(110) \\
& =\min \left(\mu_{R}(146), \mu_{G \text { Sedikit }}(110)\right) \\
& =\min (0.30769231,0.90909091) \\
& =0.30769231
\end{aligned}
$$


Langkah selanjutnya adalah mencari komposisi aturan dengan metode max (maksimum). Dari inferensi metode mamdani diperoleh derajat kebenaran untuk kasus ini sebagai berikut.

Derajat kebenaran himpunan Tidak Ada

$$
\begin{aligned}
& =\max \left(\alpha_{1}, \alpha_{4}\right) \\
& =\max (0.31428571,0.31428571) \\
& =0.31428571 \\
& =\max \left(\alpha_{2}, \alpha_{6}\right) \\
& =\max (0.30769231,0.30769231) \\
& =0.30769231
\end{aligned}
$$

Derajat kebenaran himpunan Sedikit

Berikut merupakan gambar gabungan himpunan-himpunan pada hasil yang terbagi menjadi 5 bidang yaitu D1, D2, D3, D4, dan D5 yang dapat dilihat pada Gambar 5.

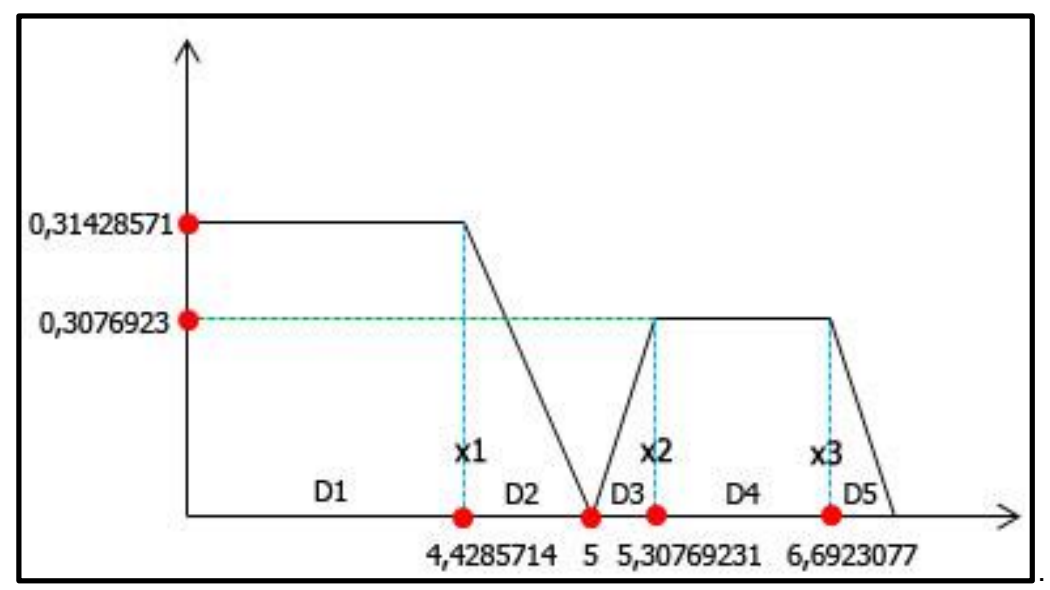

Gambar 5 : Daerah Hasil Inferensi Variabel Output

\subsubsection{Penegasan (defuzzyfikasi)}

Proses defuzzyfikasi dilakukan dengan menggunakan metode centroid. Daerah hasil inferensi variabel output akan dihitung masing-masing momen dan luasnya.

Bagian pertama (D1)

Momen dihitung dengan :

$$
\begin{aligned}
M 1 & =\int_{0}^{4,4285714} 0,31428571 x d x \\
& =3,081924116457727
\end{aligned}
$$

Luas dihitung dengan :

$$
\begin{aligned}
L 1 & =4,4285714 \times 0,31426571 \\
& =1,39174814
\end{aligned}
$$

\section{Bagian kedua (D2)}

Momen dihitung dengan :

$$
\begin{aligned}
M 2 & =\int_{4,4285714}^{5} \frac{5-x}{5} x d x \\
& =0,1508260591642376
\end{aligned}
$$

Luas dihitung dengan : 


$$
L 2=\frac{(5-4,4285714) \times 0,31426571}{2}
$$$$
=0.08979021
$$

Bagian ketiga (D3)

Momen dihitung dengan :

$$
\begin{aligned}
\text { M3 } & =\int_{5}^{5,3079231} \frac{x-5}{1} x d x \\
& =0,2467736662303319
\end{aligned}
$$

Luas dihitung dengan :

$$
L 3=\frac{(5,30769231-5) \times 0,3076923}{2}
$$

$$
=0,04737278
$$

Bagian ke-empat (D4)

Momen dihitung dengan :

$$
\begin{aligned}
\text { M4 } & =\int_{5,3079231}^{6,6923077} 0,3076923 x d x \\
& =2,55583621238201
\end{aligned}
$$

Luas dihitung dengan :

$$
\begin{aligned}
& L 4=0,3076923 \times(6,6923077-5,307692331) \\
& =0,42596448
\end{aligned}
$$

Bagian ke-lima (D5)

Momen dihitung dengan :

$$
\begin{aligned}
\text { M5 } & =\int_{6,6923077}^{7} \frac{7-x}{1} x d x \\
& =0,3216507200121375
\end{aligned}
$$

Luas dihitung dengan :

$$
\begin{aligned}
L 5 & =\frac{(7-6,6923077) \times 0,3076923}{2} \\
& =0,04733723
\end{aligned}
$$

Dengan menggunakan metode titik pusat (centroid) nilai hasil adalah sebagai berikut :

$$
\begin{aligned}
d^{*} & =\frac{M 1+M 2+M 3+M 4+M 5}{L 1+L 2+L 3+L 4+L 5} \\
& =\frac{6,35701077}{2,00221284} \\
& =3,17499251
\end{aligned}
$$

Jadi, jika sensor warna TCS 3200 mendeteksi berdasarkan frekuensi Red $=146$, dan Green = 110 maka akan menghasilkan output 3,17499251 yang kalau dilihat pada variabel output akan berada di himpunan fuzzy Non Boraks.

\subsection{Pembahasan}

Dalam penelitian ini telah dihasilkan sebuah alat pendeteksi boraks pada bakso dengan menggunakan logika fuzzy berbasis android. Untuk dapat mendeteksi boraks pada bakso alat ini menggunakan sensor warna TCS 3200 yang berfungsi untuk mendeteksi frekuensi warna dasar RG(Red and Green) pada bakso. Kemudian hasil deteksi akan diolah oleh mikrokontroler pada Arduino Uno R3. Mikrokontroler tersebut akan secara otomatis mengolah data dengan logika fuzzy dan menghasilkan output. Selanjutnya nilai output akan ditampilkan pada aplikasi yang telah dibuat pada perangkat android dengan koneksi bluetooth.

Untuk pengerjaan secara manual data yang diambil adalah salah satu data dari lampiran 1 yaitu Red $=146$, dan Green $=110$. Hasil yang telah diperoleh secara manual adalah 3,17499251 yang menyatakan bakso tidak mengandung boraks. Dalam hal ini dapat dibandingkan keluaran dari alat yang diketahui adalah 3,19 yang menyatakan bakso tidak 
mengandung boraks(Non Boraks). Sehingga dapat dikatakan hasil yang dikerjakan secara manual sama dengan hasil pada alat tersebut. Ini menunjukkan proses fuzzy yang bekerja pada alat bekerja dengan baik menggunakan sample sebanyak 12 bakso dengan akurasi alat $75 \%$.

\section{KESIMPULAN}

Berdasarkan hasil dan pembahasan yang telah dilakukan, dapat ditarik beberapa kesimpulan sebagai berikut :

1. Lampu LED (Light Emitting Diode) dirancang dengan supply pin mikrokontroler sebagai perangkat yang membantu kinerja dari sensor warna TCS 3200 sebagai bias cahaya untuk mendeteksi bakso yang mengandung boraks dan bakso yang tidak mengandung boraks.

2. Metode logika fuzzy dapat bekerja dengan baik dalam pengambilan keputusan penentuan bakso yang tidak mengandung boraks dan bakso yang mengandung boraks. Hal ini dapat dilihat dari proses perhitungan dengan menggunakan data bakso yang tidak mengandung boraks pada lampiran 1. Kemudian hasil yang telah diperoleh secara manual adalah 3,17499251 yang menyatakan bakso tidak mengandung boraks. Dalam hal ini dapat dibandingkan keluaran dari alat yang diketahui adalah 3,19 yang menyatakan bakso tidak mengandung boraks(Non Boraks). Maka keluaran yang dihasilkan oleh alat sama dengan keluaran yang dihasilkan oleh pengerjaan manual yaitu sama-sama menyatakan bahwa bakso tidak mengandung boraks (Non Boraks).

3. Aplikasi berbasis android untuk mendeteksi bakso yang mengandung boraks dan tidak mengandung boraks dirancang dengan menggunakan mikrokontroler sebagai perangkat akusisi data, sensor warna TCS 3200 sebagai penginput data, perangkat android sebagai monitor hasil dan bluetooth sebagai penghubung perangkat mikrokontroler dan perangkat android. 


\section{DAFTAR PUSTAKA}

[1] Kamus Besar Bahasa Indonesia, Bakso: http://kbbi.web.id/bakso, 2017, Diakses tanggal 3 Juni 2017.

[2] Kamus Besar Bahasa Indonesia, Boraks: http://kbbi.web.id/boraks, 2017, Diakses tanggal 3 Juni 2017.

[3] Universitas Negeri Yogyakarta, Paper Test Kit Sederhana Untuk Analisis Kadar Boraks dalam Makanan: https://fmipa.uny.ac.id/berita/paper-test-kit-sederhana-untuk-analisis-kadarboraks-dalam-makanan.html, Diakses tanggal 23 April 2017.

[4] Frans Susilo, SJ. Himpunan dan Logika Kubur Serta Aplikasinya. Yogyakarta: Graha IImu. 2003.

[5] Kusumadewi, Sri. Aplikasi Logika Fuzzy untuk Pendukung Keputusan. Yogyakarta: Graha llmu. 2013.

[6] Kusumadewi, Sri dan Purnomo, Hari. Aplikasi Logika Fuzzy untuk Pendukung Keputusan. Edisi Pertama. Yogyakarta: Graha IImu. 2004 